\title{
A RESSIGNIFICAÇÃO DO ENSINO DE LEITURA PROPICIADA PELA FORMAÇÃO DOCENTE: UM ESTUDO DE CASO A PARTIR DE NARRATIVAS DE VIDA
}

\author{
Francisco Rogiellyson da Silva Andrade \\ Priscila Sandra Ramos de Lima** \\ Dannytza Serra Gomes**
}

RESUMO: Neste artigo, que é decorrente de nossos estudos no curso de Mestrado, temos como objetivo principal analisar concepções de leitura que emergem a partir da narrativa de experiência e de práxis sobre leitura de uma professora alfabetizadora que, à época em que foi entrevistada, ainda era estudante de graduação em Pedagogia. Para isso, partimos das considerações teóricas de Kleiman (1997), Silva (1999), Koch; Elias (2012) e Braggio (1992), autores que sintetizam as principais concepções de leitura que norteiam as ações pedagógicas no âmbito do ensino dessa habilidade. Metodologicamente, estabelecemos diálogo entre a etnossociologia de Bertaux (2010) e a abordagem clínica de coleta e análise de dados proposta por Vasconcelos (2005), defendendo uma metodologia que adota como objeto de análise narrativas de vida numa perspectiva indutiva de construção de hipóteses, com base nos estudos de caso. A análise demonstra que as experiências da professora, em sua narração, foram traumáticas, pois eram somente uma maneira de avaliar a interpretação. Em decorrência disso, as discussões teórico-metodológicas acadêmicas ressignificam a maneira como a professora seleciona atividades para trabalhar a leitura. Conclui-se que é importante uma sólida formação profissional universitária inicial e continuada que possa fazer os docentes repensarem suas concepções e metodologias.

PALAVRAS-CHAVE: Concepções de leitura; Ensino de leitura; Formação docente.

\section{Introdução}

Afirma Silva (1999, p. 11) que "[...] a maneira como uma pessoa pensa um determinado processo [...] influencia diretamente as suas formas de agir quando esse processo for acionado na prática, em situações concretas de vida". Entendemos, com isso, que, além da própria formação profissional, também e principalmente as experiências que vivenciamos

\footnotetext{
* Doutorando em Linguística pela Universidade Federal do Ceará (UFC).

** Mestra em Linguística pela Universidade Federal do Ceará e professora de Língua Inglesa na Secretaria Estadual da Educação do Ceará.

*** Doutora em Linguística pela Universidade Federal do Ceará (UFC). Professora do Programa de Pós-Graduação em Linguística da UFC. Realizou estágio de pós-doutoramento em Ciências da Educação pela Universidade do Porto.
} 
ao longo da vida influenciam nossas escolhas pedagógicas. Caso a experienciação desse processo não tenha sido relativamente produtiva, é a formação profissional continuada que, potencialmente, promove a ressignificação de nossas ações.

Com base nessa problematização, neste artigo, objetivamos analisar uma narrativa de experiências e de práxis sobre leitura realizada por uma professora alfabetizadora que também é estudante de licenciatura em Pedagogia. Acreditamos que é importante perceber como essa docente experienciou a leitura ao longo da vida e como essas experiências influenciam, à luz de sua aprendizagem acadêmica, suas escolhas metodológicas acerca do ensino da leitura. Hipotetizamos que, via narrativa, a professora tem a possibilidade de ressignificar as experiências que viveu, com o fito de tornar a aprendizagem de leitura de seus alunos mais produtiva.

Nesse viés, para atingir esse objetivo, organizamos este texto da seguinte maneira: após esta introdução, apresentamos a discussão teórica que abaliza nossa análise, estabelecendo diálogo entre os principais autores que explanaram acerca das concepções de leitura. Após isso, realizamos a descrição da metodologia que viabilizou nossa coleta e análise de dados. Depois, analisamos a narrativa da participante com vistas a perceber as concepções de leitura que emergem de sua fala. Por fim, apresentamos nossas considerações finais.

\section{Referencial teórico}

Uma vez que pretendemos analisar nosso corpus de pesquisa à luz das principais concepções de leitura, faz-se necessário evidenciar que concepções são essas e como a leitura é interpretada na ótica de cada uma delas. Kleiman (1997), por exemplo, ao analisar concepções de leitura percebidas a partir de atuações de professores e de atividades de livros didáticos de língua portuguesa, inicia sua discussão afirmando que existem duas concepções de leitura socialmente difundidas. A primeira delas, que se fundamenta na ideia de que o texto é um conjunto de elementos gramaticais, entende a leitura como um processo de decodificação. Nessa ótica, o ato de ler é visto como uma atividade autônoma, que não transforma a visão de mundo do leitor, pois este não necessita realizar inferências nem mobilizar conhecimentos de mundo, apenas localizar informações no texto e transcrevê- 
las. Nessa concepção, mesmo quando se discute a opinião do leitor acerca do tema, não se problematizam as ideias do autor, não se realiza a confrontação das ideias do produtor com as do leitor, de modo que a compreensão se mostra como irrelevante. A segunda das concepções estipuladas por Kleiman (1997), com base no entendimento de que o texto é um repositório de mensagens e informações, antevê a leitura como avaliação. Nela, a leitura é vista como um processo de oralização, por meio do qual se analisa se o leitor sabe pronunciar, conforme a norma de prestígio, o texto lido. Também nessa ótica, a compreensão não é relevante tampouco a discussão, a realização de inferências nem a confrontação de ideias.

Percebendo isso, Kleiman (1997) afirma que uma alternativa a essas concepções seria aquela que percebesse a necessidade da realização de predições, inferências, confrontações, de modo a discutir as ideias do autor consoante o pensamento, a história e os discursos que emergem do leitor e do contexto de leitura que este realiza.

Koch e Elias (2012), à semelhança de Kleiman (1997), também discutem acerca das concepções de leitura, às quais sempre subjaz uma concepção de língua. Quando esta é entrevista como representação do pensamento, o sujeito é concebido numa perspectiva psicologicamente individual, alguém dono do seu dizer. Assim, na leitura, não cabe outra tarefa ao leitor a não ser a de captar a ideia do autor, ou seja, entender o que este quis dizer. Nessa concepção, chamada pelas autoras de leitura com foco no autor, a leitura é vista como captação de ideias do autor, não levando em consideração os objetivos, o contexto nem o conhecimento de mundo do leitor, pois, como dissemos, a este cabe somente a tarefa de entender o que o autor disse e repetir seu pensamento.

A outra concepção de leitura inferida por Koch e Elias (2012) é aquela que tem foco no texto. Nessa concepção, a língua é vista como uma estrutura, um código, um sistema, que se impõe aos sujeitos. Na perspectiva disso, a leitura é entendida como o processo pelo qual o leitor deve decodificar o significado tradicionalmente construído pelos signos do texto, pois tudo está dito por meio das estruturas linguísticas.

Nessas duas concepções, colocadas pelas autoras como redutoras do ato de ler, “[...] o leitor é caracterizado por realizar uma atividade de reconhecimento, de reprodução" (KOCH; ELIAS, 2012, p. 10). O que as diferencia, segundo as autoras, é que, enquanto na 
primeira o leitor deve se preocupar com as intenções do autor, na segunda, cabe ao leitor “[...] o reconhecimento das palavras e estruturas do texto" (KOCH; ELIAS, 2012, p. 10).

Com foco na interação autor-texto-leitor, Koch e Elias (2012), claramente amparadas nas ideias bakhtinianas acerca do processo de interação, defendem uma concepção em que a leitura é vista como um processo no qual o texto medeia a interação entre autor e leitor, de modo que estes dialogicamente constroem os sentidos do texto. Na perspectiva dessa abordagem, enquanto o produtor revela seus discursos e ideologias por meio de suas escolhas linguísticas e estruturas gramaticais, o leitor recupera esses construtos com vistas à compreensão. Assim, a leitura é percebida como interação, o texto como o lugar onde se dá esse processo, de modo que aspectos sociais e discursivos se imbricam. Portanto, nessa ótica, "[...] o sentido de um texto é construído na interação texto-sujeitos e não algo que preexista a essa interação. A leitura é, pois, uma atividade interativa altamente complexa de produção de sentidos” (KOCH; ELIAS, 2012, p. 11, grifos das autoras).

Nessa perspectiva, tal como afirma Cavalcante (2019), o sentido não preexiste ao texto nem mesmo está nele, mas, na verdade, é negociado, co-construído, pelos sujeitos engajados no processo de interação. No contexto disso, a leitura é vista como um processo em que se deve levar em consideração tanto as intenções do autor quanto os elementos linguísticos utilizados, mas também "[...] as experiências e os conhecimentos do leitor" (KOCH; ELIAS, 2012, p. 11), bem como os discursos e ideologias evocados pelos construtos sócio-históricos em que se circunscrevem os sujeitos.

Ainda na esteira das concepções de leitura, Silva (1999) apresenta dois grandes eixos em que várias percepções de leitura se encaixam. O primeiro deles é pelo autor batizado de concepções redutoras do ato de ler. Nesse modelo, encaixam-se visões que, segundo Silva (1999), simplificam a leitura, ou seja, que desprezam elementos sociais, histórico-culturais e ideológico-discursivos do processo de construção/produção/negociação de sentidos.

A primeira delas é a que afirma que ler é traduzir a escrita em fala. No bojo desse entendimento, lê bem aquele que oraliza bem, sabendo eloquentemente realizar as entonações e as pronúncias consideradas corretas por uma tradição. 
A segunda define que ler é decodificar mensagens. Nessa visão, a leitura é percebida como atividade em que se recupera o que quis dizer o autor. $O$ problema de entender o ato de ler concebido nessa medida é o fato de parecer que cabe ao "leitor-destinatário "receber" a mensagem [...], sem demonstrar propósitos, posicionamentos, sentimentos, atitudes [...], somente decodificar e "engolir" as mensagens dos múltiplos textos estudados" (SILVA, 1999, p. 13).

Uma terceira visão que também se filia às concepções redutoras tal como elabora Silva (1999) é a que afirma que ler é dar respostas a sinais gráficos. Essa definição de leitura, influenciada pelo behaviorismo, dá margem ao entendimento de que o professor deve incentivar o aluno a dar respostas. Caso este "acerte" a resposta já protocolada, será incentivado; caso não, será punido. Assim, diferentes interpretações acerca de um texto não são permitidas, pois o sentido (no singular) é previamente estabelecido.

Ainda no bojo das concepções redutoras apostadas por Silva (1999), encaixa-se a concepção que afirma que ler é extrair a ideia central de um texto. Nela, exige-se do leitor que saiba encontrar as ideias principais do texto - estas previamente estabelecidas. À maneira da visão anterior, também esta prevê um leitor passivo, pois desconsidera que a saliência das ideias de um texto pode variar de acordo com quem e do momento em que se lê.

Uma quinta visão entende que ler é seguir os passos da lição do livro didático. Esta, inferida pelo autor a partir de observações de aulas, dá margem ao entendimento de que a compreensão é viabilizada pelas atividades protocoladas pelo livro didático, que, segundo a análise realizada, define os seguintes passos: “(1) leitura do texto (silenciosamente e/ou em voz alta), (2) sublinhamento de palavras desconhecidas, (3) verificação do vocabulário, (4) questionário de compreensão/interpretação, (5) gramática e (6) redação" (SILVA, 1999, p. 14). Nesse construto, só compreende bem aquele que passa por essa cartilha.

A última das visões colocadas por Silva (1999) como redutoras define que ler é apreciar os clássicos. Sem desmerecer os clássicos, o autor, pelo contrário, afirma que o bom leitor é aquele que mobiliza estratégias para a leitura dos diferentes gêneros de texto, e não somente da literatura clássica, ainda mais aquela imposta como a boa e verdadeira literatura. 
Em conclusão, o autor afirma que, se agimos conforme as representações que temos, essas concepções, quando emergidas e proliferadas no âmbito social, produzem "leitores "mancos" [...] porque estarão praticando a leitura [...] a partir de paradigmas teóricos simplistas, que não levam em conta as múltiplas facetas e a essência do ato de ler" (SILVA, 1999, p. 15).

Às concepções redutoras, Silva (1999) opõe uma concepção interacionista. Para o autor, a leitura passa sempre por um mistério e uma alquimia, porque nem as diferentes disciplinas científicas nem as representações sociais são capazes de defini-la, já que o ato de ler está condicionado à história e à cultura e, por isso, transforma-se e modela-se conforme pressões sociais. Assim, Silva (1999) se filia ao que discutem Koch; Elias (2012) ao dizer que 1 - ler é interagir, pois o leitor interage com o autor, de modo a confirmar e refutar informações; 2 - ler é produzir sentidos, pois, nesse processo de interação, os leitores produzem sentidos ao que leem, de modo que o sentido não é estável, mas modelável; e 3 - ler é compreender e interpretar, pois, para Silva (1999), ao ler, o leitor realiza um projeto de compreensão que se realiza num processo de interpretação, ou seja, "o processo de interpretação demarca a abordagem do texto pelo leitor de modo que a compreensão vá se constituindo ao longo da leitura em si (Leio sempre a partir das lentes paradigmáticas ou teóricas que foram sedimentadas no meu repertório)" (SILVA, 1999, p. 17).

Em consonância com os autores acima resenhados, Braggio (1992) é uma autora que mais amplamente apresenta e discute os modelos de leitura que norteiam o ensino dessa habilidade na escola, que, na configuração da autora, são: mecanicista, psicolinguístico, interacionista e sociopsicolinguístico.

O modelo mecanicista, influenciado fortemente pelo descritivismo bloomfieldiano, segundo Braggio (1992), é a concepção em que a preocupação se encontra em fazer com que o leitor - entendido, nessa perspectiva, como uma entidade passiva -, aprenda a correspondência entre as letras e os respectivos sons que elas representam, ou seja, a relação existente entre grafemas e fonemas. Assim, esse modelo, revestido de método de ensino da leitura, na verdade, apenas faz com que o leitor oralize o que vê no papel, sem dele exigir 
a construção do sentido acerca do que lê, visto que o bom leitor é aquele que oraliza satisfatoriamente.

Nessa configuração, a leitura é vista como um comportamento a ser adquirido, por meio da exposição e da repetição. Seu foco se centra na decodificação e na gramática, sem se valer de considerações semântico-pragmáticas ou de possíveis conhecimentos prévios do leitor, já que a total correção gramatical no momento da oralização das letras revela o saber.

Além disso, a autora ressalta o fato de não haver, na concepção mecanicista de leitura, um comportamento reflexivo, ou seja, uma discussão acerca do que se lê, o que explica o mecânico, ou seja, o automatismo do método, que não procura construir uma criticidade, já que tudo que pelo texto é revelado deve ser visto como verdade absoluta.

Nessa concepção de aprendizagem de leitura, conclui Braggio (1992, p. 15), só se pode formar analfabetos funcionais, “[...] que, carentes de consciência crítica, mantêm e eternizam o status quo". Em contribuição a isso, Foucambert (1994, 2002, 2008) explica que uma visão mecanicista de ensino e aprendizagem de leitura retira da escrita aquilo que lhe é de mais intrínseco: uma linguagem feita para os olhos, em que a compreensão é atividade inerente. Assim, a oralização, que, nessa visão, é correspondente da alfabetização, se oporia à leiturização, ato de ensino da leitura. Em defesa disso, Foucambert (1994, 2002, 2008) argumenta que aquele que oraliza o que lê em língua materna sem compreender não estaria realizando uma leitura. Dessa forma, uma concepção mecanicista, segundo esse autor, apenas formaria analfabetos funcionais que, ao sair da escola e talvez não ter contatos próximos com a escrita, poderiam voltar ao analfabetismo. Longe de desconsiderar que o processo de aprendizagem da leitura é atravessado pela decodificação, quer-se dizer que a leitura não é somente um comportamento mecânico de estímulo e resposta, o que permite entrever que o ato de ler é compreensão, atividade entrevista pelo modelo psicolinguístico.

O segundo modelo apresentado por Braggio (1992) é o psicolinguístico, que se construiu a partir das concepções gerativistas da linguagem, entendida como capacidade inata dos seres humanos, com o fito de se comunicar. Dessa forma, a leitura é concebida 
também como uma atividade de comunicação, cujo objetivo é a busca pelo significado. Assim, ao ler, a mente do leitor, por meio das estruturas linguísticas, busca o significado.

Segundo a autora, por ser influenciado por uma concepção de linguagem racionalista, que prescinde de um falante-ouvinte ideal, a leitura é tida com uma atividade de linguagem ideal, desprovida de contextualização. Assim, a busca cognitiva pelo significado é o único objetivo do ato de ler.

Não se pode desconsiderar que, como mesmo acentua Braggio (1992, p. 26), do modelo mecanicista para o psicolinguístico, percorreu-se um longo caminho, uma vez que a leitura passa a ser vista como um "processo ativo, onde o leitor contribui para a construção do significado, pois traz consigo o conhecimento de sua língua". Desse modo, o modelo psicolinguístico entende o leitor como alguém que influi no processamento do significado, porém ainda entrevê uma unidirecionalidade do sujeito para o objeto, dando prevalência ao que o produtor do texto quis dizer. Mais ainda: contexto de produção, criticidade, aplicação do conhecimento de mundo do leitor na leitura que realiza, por exemplo, ainda são atividades deixadas de lado, pois o foco desse modelo seria um entendimento cognitivo de processamento da leitura. Tais considerações são melhor dimensionadas num terceiro modelo de concepção da leitura: o interacionista.

O modelo interacionista, influenciado pela sociolinguística, pelo funcionalismo, pela pragmática e pela linguística de texto, postula uma abordagem menos impactante do que foi o modelo psicolinguístico em relação ao mecanicista, mas de importância fulcral para as concepções de leitura, pois entende, tal como consideram Kock; Elias (2012), que o texto é o foco do processo de interação, o próprio lugar de interação, pelo qual interagem autor e leitor, influenciados pelo contexto de produção e de leitura, pela forma do dizer, pelos conhecimentos mobilizados na interação e pelos objetivos traçados para a leitura.

Ao centrar-se no texto numa visada interacionista, esse modelo permite que não haja uma centralidade no que quis dizer o autor, nem somente no que o leitor conseguiu extrair do texto. Entende-se, desse modo, que o texto fornece subsídios básicos para que 
haja a negociação e o compartilhamento dos conhecimentos de ambos. Consequentemente, o texto não tem uma significação fixa, já que os sentidos podem variar, a depender dos fatores sócio-históricos e subjetivos que (re)constroem a interação mediada pelo texto.

Ressaltando que esses modelos não são excludentes, pois coexistem na prática de ensino da leitura, Braggio (1992) ressalta o que, para ela, se apresenta como um redimensionamento do modelo interacionista, chamado de modelo sociopsicolinguístico. Isso se dá pelo fato de, mesmo que o modelo interacionista preveja a "[...] interação entre texto e leitor, isto é, entre texto e objeto de conhecimento, [...] terminado o ato da leitura, ambos percorrem caminhos separados. [...] Na visão sociopsicolinguística, leitor e texto não apenas se tocam, mas no [e pelo] processo se transformam" (BRAGGIO, 1992, p. 69).

Assim, a interação passa a ser vista como um processo, pelo qual texto e leitor, à medida que interagem, se transformam, numa dinâmica cooperativa em que participam "de uma situação organicamente inter-relacionada" (BRAGGIO, 1992, p. 69). Isso provoca a percepção de que, ao invés de ter seu foco na interação, o modelo sociopsicolinguístico se focaliza no encontro entre texto e leitor, o que resulta em um novo evento, uma vez que "o significado é sempre uma relação entre o texto e o contexto (sócio-histórico-cultural) e não existe à parte da interpretação de alguém daquela relação" (BRAGGIO, 1992, p. 69).

Visto nessa concepção, o ato de ler revela total protagonismo do leitor, pois é ele quem traz toda a bagagem pela qual transformará o texto e irá se transformar via leitura. Nessa perspectiva, como ressalta Braggio (1992), por apresentar uma ancoragem que revela o caráter multifacetado da leitura, seria infrutífero defender ou aplicar um método sociopsicolinguístico de leitura, já que não é possível, por meio de um único método, dar conta da diversidade de processos que resultam na construção da leitura.

Para findar sua discussão, a autora lança luz acerca do que chama de Fundamentos para um redimensionamento do modelo sociopsicolinguístico de leitura, posto que, segundo ela, ainda que concebendo o caráter multifacetado da leitura, o modelo sociopsicolinguístico, e todos os outros, concebem o homem, a sociedade e a linguagem ainda de maneira não concreta, com certa idealização. 
Seria necessário, assim, "um processo de alfabetização psicológico-social-histórico e ideologicamente voltados não só para o bom leitor como também e, principalmente, para o leitor crítico que, de posse da linguagem escrita, seja sujeito de sua práxis” (BRAGGIO, 1992, p. 94). Ou seja,

[...] É necessário que o leitor também entre em confronto com o texto, com as ideias do autor, com as suas intenções, e possa avaliar em que medida os dados disponíveis através do material escrito entram em contradição com a sua realidade. É preciso, através da linguagem escrita (mas não só através dela), construir a consciência crítica do indivíduo, possibilitando-lhe uma reflexão sobre sua realidade, uma leitura do mundo, uma leitura de sua realidade. (BRAGGIO, 1992, p. 94)

Segundo a autora, partindo desse pressuposto, evita-se o perigo de se cair no que ela chama de uma concepção de leitor ingênuo, que seria aquele que decodifica, mas não descodifica, ou seja, que entende que a linguagem é monovalente e que apenas repete os discursos, as crenças e os valores da classe dominante, sem criticá-los.

A partir de tais considerações, percebe-se que a maioria dos autores defende que deve haver, no processo de leitura, o que Leffa (2012) conceitua como compreender. Para esse autor, interpretar e compreender são atividades diferentes, mas necessárias para a construção dos sentidos. A primeira preocupa-se com a coleta das informações fornecidas pelo texto, ou seja, interpretar, na teorização de Leffa (2012), significa entender o que, por meio das construções linguísticas de um texto, quis dizer seu produtor. Dessa maneira, o leitor apega-se, de forma imanente, ao material fornecido pelo texto, a fim de poder construir seu entendimento. Nessa perspectiva, conforme também destaca Orlandi (2012), cabe ao interpretante colher o significado contido no objeto, uma vez que o leitor “[...] não inventa e nem cria, ele apenas reproduz o que supostamente preexiste na sua frente. Em suma, [...] o significado emerge do próprio objeto em direção ao leitor” (LEFFA, 2012, p. 260). Significa dizer, portanto, que, colocando-se como intérprete, o leitor “[...] faz uma leitura de mão única, recebendo passivamente as informações, sem voz para interagir ou dialogar com o texto. É alimentado diretamente pelo que lê"' (LEFFA, 2012, p. 260). 
De maneira diferente, mas dependente da interpretação, a compreensão, segundo Leffa (2012), é o ato de dar sentido ao texto, ou seja, compreender é uma maneira de o leitor significar o texto a partir de sua história de vida e de suas representações sociais, respeitando, obviamente, a interpretação do texto. Tal ideia de compreensão se filia ao que postula Braggio (1991) no redimensionamento de uma concepção sociopsicolinguística de leitura, pois entende que tanto textos quanto leitores passam por um processo de confrontação ou, nos termos que utilizamos anteriormente, de negociação de sentidos. Esse processo se inicia na interpretação, mas somente se concretiza na confrontação do texto com a realidade do leitor, etapa que ocorre na compreensão textual, ou seja, no momento em que ocorre uma transformação recíproca entre texto e leitor.

Assim, é perceptível que inúmeras forças agem, inter-relacionam-se, (co)operam, a fim de que a leitura se efetive. A importância do modelo reside no fato de, como postula Braggio (1992), o leitor ser concebido numa atividade concreta e, por isso mesmo, protagonista de sua leitura. Além disso, ainda em consonância com o dizer de Braggio (1992), não seria eficaz estipular um único modelo de ensino de leitura, tendo em vista que não há como prever, na dinâmica da interação, os agentes que a modelam.

Essa concepção ressalta a própria imprevisibilidade inerente à leitura, uma vez que não é possível afirmar quais forças entrarão em jogo para a construção da interação pelo código escrito nem mesmo os sentidos possivelmente construídos no bojo da interação. A seguir, apresentamos um quadro ilustrativo, adaptado de Franco (2011), que resume os modelos de leitura apresentados, bem como as concepções entrevistas em cada modelo. 
Quadro 1: Principais características das abordagens de leitura decodificadora, psicolinguística, interacional e complexa

\begin{tabular}{|c|c|c|c|c|}
\hline & $\begin{array}{c}\text { Abordagem Me- } \\
\text { canicista }\end{array}$ & $\begin{array}{l}\text { Abordagem Psi- } \\
\text { colinguística }\end{array}$ & $\begin{array}{l}\text { Abordagem In- } \\
\text { teracional }\end{array}$ & $\begin{array}{c}\text { Abordagem So- } \\
\text { ciopsicolinguís- } \\
\text { tica }\end{array}$ \\
\hline $\begin{array}{l}\text { Visão de lín- } \\
\text { gua(gem) }\end{array}$ & $\begin{array}{l}\text { sistema } \\
\text { estrutural }\end{array}$ & $\begin{array}{l}\text { sistema } \\
\text { mental }\end{array}$ & $\begin{array}{l}\text { sistema cognitivo } \\
\text { e social }\end{array}$ & dialógica \\
\hline Visão de leitura & $\begin{array}{l}\text { atividade } \\
\text { perceptiva }\end{array}$ & $\begin{array}{l}\text { atividade } \\
\text { cognitiva }\end{array}$ & $\begin{array}{l}\text { atividade percep- } \\
\text { tiva, cognitiva, e } \\
\text { social }\end{array}$ & $\begin{array}{l}\text { atividade com- } \\
\text { plexa e dinâmica }\end{array}$ \\
\hline $\begin{array}{l}\text { Fluxo de informa- } \\
\text { ção }\end{array}$ & Ascendente & Descendente & $\begin{array}{l}\text { bidirecional (as- } \\
\text { cendente e des- } \\
\text { cendente) }\end{array}$ & multidimensional \\
\hline Papel do Leitor & Perceptivo & Ativo & interativo & dinâmico \\
\hline Significado & $\begin{array}{l}\text { no texto (extraído } \\
\text { pelo leitor) }\end{array}$ & $\begin{array}{l}\text { na mente do leitor } \\
\text { (por meio da ati- } \\
\text { vação do conheci- } \\
\text { mento prévio) }\end{array}$ & $\begin{array}{l}\text { construído a partir } \\
\text { da interação lei- } \\
\text { tor-autor }\end{array}$ & $\begin{array}{l}\text { emerge a partir da } \\
\text { interação do leitor } \\
\text { com múltiplos ele- } \\
\text { mentos presentes } \\
\text { dentro e fora do } \\
\text { sistema de leitura }\end{array}$ \\
\hline
\end{tabular}

Fonte: adaptado de Franco (2011).

O quadro de Franco (2011) ilustra os modelos teóricos de leitura e as concepções inerentes a cada um deles. Como ressalta Braggio (1992), percebemos o grande salto existente entre a visão de leitura numa abordagem mecanicista e numa abordagem sociopsicolinguística/complexa. Tal desenvolvimento se dá, sem dúvida, pelo objetivo de se formar um leitor crítico e pela percepção de que o leitor exerce um protagonismo que direciona/redimensiona/orienta seu ato de ler.

Orientados por essas considerações, podemos perceber, portanto, que a leitura, como toda prática social, se reveste das significações sócio-históricas e culturais que lhe dão sentido. Assim, a leitura se erige na medida do verbo estar, e não do verbo ser. Com esses pressupostos, podemos, assim, empreender nossa análise. Antes, porém, descremos, no tópico a seguir, a metodologia que viabilizou nossa pesquisa. 


\section{Metodologia}

Para realizar a coleta e a análise dos dados, estabelecemos diálogo entre a perspectiva etnossociológica tal como proposta por Bertaux (2010) e a abordagem clínica de coleta e análise dos dados construída por Vasconcelos (2005).

A etnossociologia, segundo Bertaux (2010), se insere no escopo dos estudos de caso, delineia-se numa análise indutiva dos dados e tem como objeto de estudo as narrativas de vida, estas entendidas como materiais pelos quais, além de narrar fatos, os sujeitos os analisam e podem ressignificar suas concepções. Vasconcelos (2005) propõe uma coleta e análise de narrativas de vida que permitam aos sujeitos terem seus dizeres respeitados.

A clínica do discurso, segundo Vasconcelos (2005, p. 37), "se prende à escuta de uma singularidade como reveladora [...] de um vivido social. Ela visa a coletar o conhecimento específico do qual um narrador é o portador suscitando sua expressão". Vale ressaltar que a autora considera, ainda, que, na vertente clínica, surgem possibilidades de interpretação, de modo que a clínica do discurso se refere-se à uma interpretação aproximativa, e não exata. Por isso, ao analista clínico, interessa interpretar aquilo que o sujeito, emaranhado pela escolha de suas palavras, sequer imaginava que tinha o que dizer ou que queria dizer, mas, uma vez imbricado por discursos, deixa saliente em sua narração.

Se é necessário um cuidado especial do pesquisador no momento da interação com o sujeito, para que este não se sinta invadido ou julgado e para que se senta à vontade para abrir a teia de sua vida, também o momento de análise se configura primordial, pois o pesquisador deve inclinar-se ao que o sujeito diz, sem preconceitos, pré-julgamentos ou, mesmo, buscando os não-ditos. Inclinar-se, no momento de análise, significa abrir-se para o leque de sentidos e de saberes construídos pelo sujeito. A isso, Vasconcelos (2005) denomina ausculta e deontologia. A primeira se refere à tentativa de buscar os sentidos mais profundos construídos pelos sujeitos em suas narrativas, sem, contudo, invadir suas intimidades nem extrapolar os limites de seus dizeres, o que se refere à deontologia.

A escolha por narrativas de vida como objeto de estudo ocorre porque essa organização textual-discursiva, diferentemente de outras materialidades narrativas, carrega a qua- 
lidade de, ao passo que narram fatos selecionados conforme percepções subjetivas, os sujeitos poderem refletir acerca dessas experiências. Em consequência disso, afirma Josso (2010), a narrativa tem um caráter autoformador, uma vez que, por meio da reflexão que realiza, o sujeito tem a possibilidade de ressignificar seu agir, com vistas a transformar suas ações. Nesse contexto, de acordo com Ribeiro (2008, p. 42), a narrativa "se revela como um meio capaz de provocar o enfrentamento das representações individuais e coletivas emersas na enunciação, o que, inevitavelmente, resultará, em menor ou maior grau, na (re)estruturação da identidade do locutor". Através da narrativa de vida, os sujeitos (re)apresentam e (re)constroem sentimentos, sensações, representações, que são avaliadas e transformadas através de um processo metacognitivo, de maneira que, via narrativa,

[...] os referentes sobre a prática educativa são introduzidos, retomados e deslocados continuamente na enunciação, conferindo à dinâmica discursiva um fluxo capaz de provocar processos metacognitivos e (trans)formações no agir comunicativo do sujeito que enuncia. Quando o sujeito fala de seus sentimentos, de suas impressões, expõe seus julgamentos e se posiciona, necessariamente avalia maneiras de ser na prática educativa e, portanto, (re)visita e ressignifica aspectos identitários da figura do professor. Essa situação avaliativa a que o locutor se sujeita [...] consiste na mediação de operações metacognitivas que levarão a uma mudança de status na ordem social. (RIBEIRO, 2008, p. 42).

O desdobramento disso, no que se refere a professores, se reflete nas escolhas metodológicas empreendidas na práxis, cooperando para uma aula de leitura produtiva. Dessa forma, à medida que geramos os dados, também fornecemos aos participantes a possibilidade de pensar suas concepções sobre o ensino de leitura e sobre sua formação leitora, (re)avaliando esses conceitos sobre o ato de ler e sobre o ensino dessa habilidade.

Assim, à luz de uma conversa cujo mote era "conte como foi sua aprendizagem de leitura e suas experiências com a leitura", coletamos a narrativa de vida de uma professora que aqui damos o nome-fantasia de Vitória. Escolhemos esse pseudônimo em função de, como veremos em nossa análise, percebermos que a professora narra uma história de superação que se realizou em suas práticas docentes na aula de leitura, em comparação ao que vivenciou ao longo da vida no que se refere à aprendizagem da leitura. Ressaltamos 
que, sob a condição de ter sua identidade protegida, a participante assinou o termo de esclarecimento e consentimento livre para esta pesquisa.

Vitória, à época em que foi entrevistada, tinha 24 anos e era estudante de graduação em Pedagogia. Apesar de ainda estudante, ela já atuava como docente de turmas dos anos iniciais do Ensino Fundamental de escolas particulares de Fortaleza desde 2015. A entrevista com P5 ocorreu na casa de sua avó, onde passava alguns dias. A docente estava de licença saúde por conta de problemas psicológicos que, segundo ela, a acometeram em virtude da rotina escolar. Quando não estava de licença, ela lecionava aulas de todas as disciplinas para duas turmas de terceiro ano dos anos iniciais do Ensino Fundamental.

A seguir, apresentamos a discussão e a análise da narrativa de Vitória, com base na metodologia aqui descrita.

\section{Análise e discussão}

Vitória afirma não se recordar bem dos tempos de alfabetização, por isso inicia sua narrativa já da época em que cursava os anos iniciais do Ensino Fundamental:

Eu lembro da terceira série, [...] lendo um texto bem bonito pra sala toda, tendo uma leitura boa [...]. Sendo bem realista, era leitura e escrita totalmente voltado pra escola, pra fazer prova, pra passar pra série seguinte e pronto. Eu não tinha uma leitura crítica e eu não sei se eu seria capaz de, em pleno terceiro ano... Mas, no quarto ano, eu já... Se eu fosse fazer alguma leitura, eu tinha uma professora que fazia mais esse processo de reflexão, mas, do terceiro ano pra trás, leitura, paradidático, só pra resolver questões, só isso. Eu acho que não teve aquela coisa do lúdico, do brincar pra aprender nem aprender brincando. Nem nada que tenha tocado. A gente brincava no recreio a brincadeira que a gente quisesse.

O trecho em destaque da narrativa de Vitória salienta a questão de, mesmo num período posterior ao de alfabetização, ainda se presar pelo domínio da oralização do texto verbal. Como vimos anteriormente em Foucambert (1994), a boa cadência na oralização da escrita não garante, por si, a construção dos sentidos do texto. A própria narradora, ao refletir sobre essa etapa de sua vida, ressalta que não houve uma leitura crítica. $\mathrm{Na}$ esteira disso, fica-se a pergunta, que a narradora deixa entrever: o que seria uma leitura crítica, ainda mais para crianças? Os Parâmetros Curriculares Nacionais e a Base Nacional Comum Curricular, bem como autores como Koch; Elias (2012), Freire (2003) e Freire; Macedo 
(1994), permitem que entendamos a leitura crítica como uma maneira de refletir sobre o mundo e sobre a sociedade. Mesmo ainda em séries iniciais, essa atividade se torna possível, se consideramos gêneros como fábulas, contos de fadas, histórias em quadrinhos ou notícias. Tais gêneros, circulantes na vida social dos aprendizes, permitem, a partir de uma linguagem acessível, a reflexão sobre nossas atitudes frente ao mundo e à sociedade, ato que, segundo narra Vitória, não ocorreu nas aulas de que participou.

Ainda no que se refere ao mesmo trecho, parece que a concepção de leitura que sintetiza o ato de ler como resumir as ideias do produtor, tal como formula Silva (1999), fica saliente. Ao afirmar que "era leitura [...] pra fazer prova, pra passar pra série seguinte”, a narradora permite a inferência de que sua experiência passa pelo conceito de interpretação (LEFFA, 2012) quanto ao fato de que sua tarefa se resumia a colher dos textos as ideias do autor, nos moldes sintetizados por Koch; Elias (2012) como leitura com foco no texto e por Silva (1999) como ler é extrair a ideia central de um texto. Tal experiência enfatiza o letramento dominante e as práticas protocoladas de leitura (STREET, 2014), como se a compreensão, nos termos em que a define Leffa (2012), se encaixasse em fórmulas específicas. Tal reflexão se confirma na continuidade da narrativa de Vitória:

Quando eu acordei pra vida no ensino médio, porque, como eu te disse, na minha escola, era muito aquela coisa decorativa: eu estudava um texto na maior e apresentava ele na maior, mas, minutos depois, se fosse perguntar, eu não saberia dizer o que eu tinha falado. E, no ensino médio, quando eu acordei pra vida, no segundo ano, eu participei do Soletrando, aí fui pra final, foi o mais longe que eu consegui. Aí, quando foi no terceiro ano, que eu me pegava naqueles simulados, estilo ENEM, [...] eu não me dava muito bem com aquilo. E acabava o horário da prova, eu não tinha respondido nem metade, e o diretor tirava a prova da minha mão de todo jeito e foi aí meu bater de frente com a leitura, de, com a leitura com interpretação, através daqueles simulados, aulões, essas coisas... Foi aí que eu... Entrei em choque.

Nesse trecho, a narradora apresenta o que parecem ser para ela evidências de que realmente a leitura que ela aprendera se efetivava apenas para cumprimento das obrigações escolares. O “choque” que ela afirma ter sentido no Ensino Médio se dá em razão de, nessa etapa, ela ter começado a perceber que essa maneira de ler não era a conveniente a todos os campos de atuação, mesmo os educacionais, considerando simulados e avaliações de larga escala. Inclusive, ao utilizar a expressão "acordar para a vida", a professora indicia 
essa percepção de que somente oralizar ou interpretar superficialmente os textos não eram as únicas habilidades requeridas para as práticas escolares. Assim, como dito em nossa metodologia, embasados em Ribeiro (2008) e Josso (2010), via narrativa de vida, Vitória, após ativar conhecimentos aprendidos ao longo de sua formação em Pedagogia, ressignifica suas experiências, atualizando-as como ações de que deseja se afastar na práxis. Podemos ver isso a seguir, quando Vitória muda o tom de sua narrativa:

[Hoje] A leitura tem demais espaço na minha vida. É bem complexa hoje pra mim, porque qualquer assunto polêmico que você vá estudar, vá ler [...] é complexo. [...] uma vírgula num lugar errado já pode significar outra coisa. Então, hoje em dia, eu associo a leitura a estudar. Então, fica muito complexo. Se eu quero uma opinião contra ou a favor, como é que eu vou escrever isso, [...] seja num artigo ou em qualquer trabalho que eu venha a fazer. Hoje em dia, eu associo a leitura muito a estudar. E com os alunos também. Com as crianças também. [...] Como eu estou de licença, eu li Victor Hugo, Machado de Assis, Paulo Freire, "A Menina que Roubava Livros", talvez aquilo, se fosse imposto pra eu estudar e ler e responder a prova, eu teria um ódio, mas, como eu tava lendo por bobby, por querer saber da história, não era nenhuma tortura, não. Me fez lembrar de coisas que, coisa bem longínquas, o tempo de Hitler, que era assim, tudo vem de uma meninazinha que roubava livro, que vai ser adotada, a família pensa que é um menino e é uma menina, e aí ela gosta de roubar livros quando dá oportunidade, e tinha, né, aquelas lutas, guerras... Não me tocou, me fez bem de poder estar em casa e ler o que eu quero. Me toca quando realmente, as poesias... Bráulio Bessa, eu amo! Poesias e tal, que eu escuto na faculdade. É de arrancar o coração. Machado de Assis, eu lendo lá “A Mão e a Luva” e achando ótimo, eu lendo lá "Os Miseráveis" e acho até que já tinha lido, e li de novo, se fosse pra fazer uma prova, eu amei ler. Quando você vai fazer uma coisa que já é regra, você acha chato, quando não...

Vitória afirma ter conseguido desescolarizar a leitura agora, já adulta. Assim, ela apresenta uma virada no processo de leitura que exercita, passando a acreditar no processo, a partir do gosto e do olhar mais crítico para a interpretação. Em sua narração, a professora enfatiza que, se fosse uma cobrança escolar, certamente, não gostaria da atividade de ler, mas, não sendo nesse contexto, a leitura lhe toca. Dessa maneira, entende-se que, apesar de suas experiências terem sido redutoras, a leitura, hoje, é uma opção de divertimento. Além disso, ao afirmar que "uma vírgula muda tudo", a narradora lembra o que Koch; Elias (2012) ressaltam acerca dos subsídios que o produtor fornece ao leitor para que, dentro de uma demarcação histórico-social, interajam. É nesse bojo que a narradora encaixa suas experiências, ao dizer que pode refletir sobre a História e sobre sua própria vida a partir das leituras que realiza (ORLANDI, 2012). 
Ainda sobre o mesmo trecho, ao falar que a leitura equivale a estudo, podemos inferir que, de encontro aos estudos que tinha que fazer antes, agora o ato de ler tem a ver com a maneira encontrada por Vitória para analisar diferentes informações que ela recebe, construindo um posicionamento seu sobre questões que para ela são colocadas. Isso deixa entrever, como percebem Braggio (1992) e Freire (2003), que a leitura é uma interação que permite aos interactantes saírem transformados através da negociação de sentidos propiciada pelo texto. Nessa visão, podemos entender, com Freire (2003), que Vitória, ao ler o mundo via leitura da palavra, pode transformar a leitura de seu mundo, chegando ao que Braggio (1992) chama de descodificar o código escrito, ou seja, à leitura crítica.

Ao fim da narrativa de suas experiências, a alfabetizadora afirma que, hoje, fora do sistema educacional básico como estudante e em consequência de sua licença-saúde, ela pode ter momentos de prazer e entretenimento através de leitura. Ao que parece, esse entendimento de que a leitura deve ser motivo de prazer para os sujeitos é transposto pela professora para a sua práxis pedagógica:

Eu não acho correto colocar, trabalhar com crianças até fundamental I essa questão de ler pouco, essas coisas... Eles podem não gostar... Porque é difícil fazer com que uma criança aprenda a gostar de ler, seja crítico e tal, mas é inventar, criar, sair da mesmice e criar novos modelos de interpretação e leitura em que a criança não perceba isso só como um texto que ela tem que ler. A partir do momento que eu faço uma dinâmica, com aquele objetivo, eu peço pra eles escreverem uma redação, dizendo o que eles gostaram, o que eles aprenderam, porque, quando se trata de enunciados, essas coisas, uma prova, né, que hoje a forma avaliativa são provas e tal, isso são os colégios tradicionais, eu não concordo, né, com esse enunciado grande demais, cansativo, eu acho muita crueldade. Isso marcou pra eu não fazer com meus alunos, principalmente tão novos. Eu levo jogos até o Fundamental I.

Como narra a professora, ao invés de solicitar que os seus alunos respondam a questionários que, como analisam Leffa (2012) e Silva (1999), procuram medir a leitura e pouco objetivam à compreensão textual, Vitória procura pedir-lhes que relatem suas experiências com a leitura. Dessa maneira, os estudantes podem se sentir mais livres para comentar suas impressões acerca do que leem e percebem que podem ter sua própria análise textual. Larrosa (1996) afirma que o sistema educacional hodierno dá prioridade a dados estatísticos, portanto necessário se faz basear-se em interpretações textuais pré-definidas, a fim de poder fornecer números educacionais, o que impede, entre outras, a experiência de 
leitura. De encontro a esse sistema, ao invés de sucumbir às pressões que lhe são impostas, Vitória procura oportunizar a experienciação leitora de seus alunos. Essa evidência se mostra relevante porque, como salientamos, a narradora é professora de escola particular, onde, segundo pensa ela, as exigências são mais impositivas em relação ao ensino público, que prioriza pela pluralidade de práticas pedagógicas. Além disso, Vitória ainda é aluna de graduação, o que demonstra seu engajamento profissional com uma aprendizagem da leitura mais voltada para a construção de sentidos. O fato de essa narradora ainda ser graduanda pode sinalizar a relevância das discussões do curso para a transformação das representações de leitura dos futuros professores. Como vimos, Pineau e Le Grand (2012) consideram que o único tempo que pode ser alterado é o passado, o que significa dizer que, conforme nossas experiências, a forma como interpretamos os fatos podem ser ressignificados. Considerando isso, quando analisamos a narração de algumas das experiências de Vitória, percebemos certo otimismo, já que se circunscreveram a momentos felizes de sua infância. Porém, na narração de sua práxis, a professora confronta a metodologia de ensino da leitura que experienciou com o que aprende no Curso de Pedagogia, de modo que passa a narrar suas experiências como traumáticas. Tal trauma é superado por meio de suas escolhas metodológicas para o ensino da leitura, que, segundo conta, se afastam das por ela experienciadas, o que, uma vez mais, nos remete ao caráter autoformador da narrativa (JOSSO, 2010), que possibilita ao narrador uma transformação de si (VASCONCELOS, 2005).

Nessa ancoragem, no que se refere à narração de experiências de aprendizagem e das escolhas metodológicas que empreende para o ensino da leitura, percebe-se que a oportunidade de narrar a vida propiciou a Vitória uma ressignificação sobre o que vem a ser a leitura. Como viemos salientando, inicialmente, ainda que explique que, fora de sua identidade docente, suas experiências foram lúdicas, sob a lente da pedagoga em formação, porém, sua aprendizagem de leitura não fora significativa para a formação de uma leitora crítica. Se repetidas essas experiências na práxis, portanto, a narradora concebe que também não formaria leitores proficientes. 
Ainda, por meio da narrativa de vida, Vitória, ao passo que narra suas escolhas metodológicas para o ensino de leitura, (re)afirma que elas se afastam das metodologias empreendidas por suas professoras, o que demonstra, como diz Ribeiro (2008), a importância de os docentes narrarem sua vida, já que, através desse processo, há uma ressignificação de seu agir, o que, no que se refere à leitura e a seu ensino, potencialmente oportuniza uma aula de leitura produtiva e afinada com as orientações estabelecidas por documentos oficiais, como a BNCC (2018) e os PCN (1998).

Ainda no que se refere à narrativa de práxis de $\mathrm{P} 5$, o trabalho com a ludicidade, tal como afirma a professora ao dizer que utiliza dinâmicas e jogos, certamente, abre espaço para que os estudantes construam a interpretação leitora, dividam suas opiniões e impressões e concretizem sua compreensão (LEFFA, 2012). Dessa maneira, percebe-se que Vitória utiliza essa metodologia orientada por objetivos pedagogicamente delineados à luz de perspectivas mais interacionais de linguagem. Nesse contexto, ela analisa suas experiências de leitura no ambiente educacional como traumáticas, no entanto narra que, com seus alunos, realiza o oposto do que experienciou, dando a eles a possibilidade de construir experiências de leitura.

\section{Considerações finais}

A análise da narrativa de Vitória permite a percepção de que suas experiências, em sua maioria, primaram por concepções redutoras de leitura, pois a professora dá saliência à oralização do código escrito e a atividades que não a permitiam construir criticamente a leitura. De encontro a isso, atualmente, em suas práticas leitoras, ela procura sempre fazer uma seleção minuciosa de materiais escritos, que lhes permitam uma releitura do mundo.

Ainda que a narração de Vitória, em algum momentos, trate de ocasiões em que se sentia feliz nas atividades de leitura para ela impostas, ao mobilizar os conhecimentos científicos com os quais têm contato no curso de licenciatura em Pedagogia, a professora ressignifica sua aprendizagem, afirmando que esse processo não the permitiu ser uma leitora crítica. Em função disso, como professora de uma turma de alfabetização, ela procura 
selecionar metodologias que permitam aos estudantes confrontarem seu conhecimento com o fornecido pelo material textual, de modo a construir progressivamente a criticidade.

Em torno disso, as experiências de Vitória, como ela própria narra, foram traumáticas, pois se efetivaram dentro de concepções redutoras de leitura, mas se configuraram como importantes para que, em sua atuação docente, primasse por uma ludicidade com seus estudantes, de modo a dar a eles liberdade para que possam construir os sentidos dos textos que leem, ao invés de repetir interpretações protocoladas aprioristicamente, ao contrário do que a professora experienciou.

Esse movimento revela, a nosso ver, a importância da narrativa de vida para o processo de formação inicial e continuada do profissional docente, já que, por meio da narração e da análise dos fatos vivenciados ao longo da vida referentes a um dado objeto de discurso, o sujeito empreende uma seleção minuciosa de experiências que deseja compartilhar, seja para delas se aproximar, seja para delas se afastar, o que produz uma ressignificação do seu agir, já que, ao longo desse complexo processo de enunciar uma narrativa da vida, o narrador mobiliza conhecimentos de diferentes ordens discursivas os quais permitem uma (re)orientação das concepções que se atualizam no discurso construído narrativamente e, consequentemente, das ações empreendidas em suas práxis pedagógicas.

Além disso, é fulcral observar que Vitória ainda está cursando a graduação, o que nos leva a inferir, a partir do que a própria narradora reflete, que a efervescência dos debates nas aulas do curso influenciam para que ela conceba suas experiências como traumáticas e procure superá-las por meio de sua práxis. Assim, concluímos que a formação profissional universitária inicial e continuada, principalmente no que se refere ao exercício da docência, se torna passo importante para que os professores possam ressignificar suas concepções e, consequentemente, pensem em metodologias que oportunizem a formação de cidadãos mais críticos e reflexivos, tal como preconiza a atual Lei de Diretrizes e Base da Educação (1996). 


\section{THE REFRAME OF READING TEACHING PROVIDE BY TEACHER TRAINING: A CASE STUDY FROM LIFE NARRATIVES}

ABSTRACT: In this article, which is a result of our studies in the Master's course, we have as main objective to analyze conceptions of reading that emerge from the narrative of experience and praxis about reading by a literacy teacher who, at the time she was interviewed, was still graduate student in Pedagogy. For this, we start from the theoretical considerations of Kleiman (1997), Silva (1999), Koch; Elias (2012) and Braggio (1992), authors who synthesize the main conceptions of reading that guide pedagogical actions within the scope of teaching this skill. Methodologically, we established a dialogue between the ethnosociology of Bertaux (2010) and the clinical data collection and analysis approach proposed by Vasconcelos (2005), defending a methodology that adopts life narratives as an object of analysis in an inductive perspective of hypothesis construction, based on the case studies. The analysis shows that the experiences of the teacher, in her narration, were traumatic, as they were only a way to evaluate the interpretation. As a result, the theoretical-methodological discussions reframed the way the teacher selects activities to work on reading. We conclude that it is important to have a solid initial and continuous professional training that can make teachers always rethink their conceptions and methodologies.

KEYWORDS: Conceptions of reading; Teaching reading; Teacher training.

\section{REFERÊNCIAS}

BERTAUX, D. Narrativas de vida: a pesquisa e seus métodos. Tradução de Zuleide Alves Cardoso Cavalcante e Denise Maria Gurgel Lavallée. São Paulo: Paulus, 2010.

BRAGGIO, S. L. B. Leitura e alfabetização: da concepção mecanicista à sociopsicolinguística. Porto Alegre: Artes Médicas, 1992.

BRASIL. Ministério da Educação. Lei de Diretrizues e Bases da Educação Nacional. Disponível em: <http://www.planalto.gov.br>. Acesso em 10 de agosto de 2019.

. Parâmetros curriculares nacionais: $3^{\circ}$ e $4^{\circ}$ ciclos do Ensino Fundamental: Língua Portuguesa. Brasília: MEC/SEF, 1998.

Base nacional comum curricular. Brasília: MEC/SEF, 1998.

CAVALCANTE, M. M. Entrevista com Mônica Cavalcante. Entrevistadora: Associação Brasileira de Linguística - ABRALIN. Entrevistada: Mônica Magalhães Cavalcante. Campinas: ABRALIN, 01 mar. 2019. Podcast. Disponível em: https://goo.gl/CDDe9u. Acesso em: 04 mar. 2019.

FOUCAMBERT, J. A leitura em questão. Tradução de Bruno Charles Magne. Porto Alegre: Artes Médicas, 1994.

- A criança, o professor e a leitura. Tradução de Marleine Cohen e Carlos Mendes Rosa. Porto Alegre: Artes Médicas, 2002.

- Modos de ser leitor: Aprendizagem e ensino da leitura no ensino fundamental.

Tradução de Lúcia P. Cherem e Suzete P. Bornatto. Curitiba: Editora UFPR, 2008. 
FRANCO, C. de P. Por uma abordagem complexa de leitura. In: TAVARES, K.; BECHER, S.; FRANCO, C. (Orgs.). Ensino de Leitura: fundamentos, práticas e reflexões para professores da era digital. Rio de Janeiro: Faculdade de Letras da UFRJ, 2011, p. 2648.

FREIRE, P. A importância do ato de ler: em três artigos que se completam. São Paulo: Cortez, 2003.

; MACEDO, D. Alfabetização: leitura do mundo leitura da palavra. São Paulo:

Paz e Terra, 1994.

JOSSO, M. Experiências de vida e Formação. Tradução de José Cláudio e Júlio Ferreira. 2 ed. Natal: EDUFRN, 2010.

KLEIMAN, A. Oficina de leitura: teoria e prática. 5. ed. São Paulo: Pontes, 1997.

KOCH, I. V. G.; ELIAS, V. M. Ler e compreender: os sentidos do texto. 3. ed. São Paulo: Contexto, 2012.

LARROSA, J. La experiencia de la lectura: estudios sobre literatura y formación. Barcelona: Laertes, 1996.

LEFFA, V. J. Interpretar não é compreender: um estudo preliminar sobre a interpretação de texto. In: __ _ ERNST, A. (Org.). Linguagens: metodologia de ensino e pesquisa. Pelotas: Educat, 2012, p. 253-269.

ORLANDI, E. P. Discurso e leitura. 9. ed. São Paulo: Cortez, 2012.

PINEAU, G.; LE GRAND, Jean-Louis. As histórias de vida. Tradução de Carlos Eduardo Galvão Braga e Maria da Conceição Passegi. Natal: EDUFRN, 2012.

RIBEIRO, P. B. O discurso docente (re)velado no gênero memorial. 2008. 293 f. Tese (Doutorado em Letras) - Programa de Pós-Graduação em Letras, Pontifícia Universidade Católica de Minas Gerais, Belo Horizonte, 2008.

SILVA, E. T. Concepções de leitura e suas consequências no ensino. Perspectiva, Florianópolis, v. 17, n. 31, p. 11-19, jan./jun. 1999.

STREET, B. V. Letramentos sociais: abordagens críticas do letramento no desenvolvimento, na etnografia e na educação. Tradução de Marcos Bagno. 1. ed. São Paulo: Parábola Editorial, 2014.

VASCONCELOS, S. Clínica do Discurso: a arte da escuta. Fortaleza: Premius, 2005.

Recebido em: 28/04/2020.

Aprovado em: 11/06/2020. 